The BDJ News section accepts items that include general news, latest research and diary events that interest our readers. Press releases or articles may be edited, and should include a colour photograph if possible. Please direct your correspondence to the News Editor, Arveen Bajaj at the BDJ, 64 Wimpole Street WIG 8YS or by email to bdj@bda.org

\section{First to benefit from new bursary}

Three student dental nurses are the first to benefit from a training bursary launched by health chiefs in memory of a dedicated Oldham dental nurse who died last year. The Naveed Maqsood Training Bursary was launched after the tragic death of the 23year-old married father from cancer.

Naveed had spent two years on the PCT's bilingual dental nurse training programme before joining John Scott's dental practice in Lees. Now student dental nurses Bushra Ibrar, 31, Rohima Khatun, 21 and 20-year-old Joohora Begum will all have the chance to take part in extra training to improve their skills and help their patients.

They will use the bursary for courses in healthcare and health promotion, inhalation and sedation and oral health promotion.

\section{New Chair in Wales}

Dr Jeremy Rees has recently been appointed to a Chair in Restorative Dentistry at the University of Wales College of Medicine.

He graduated from Cardiff in 1984 and was Lecturer in Restorative Dentistry at Cardiff from 1989-1996. For the last six years Dr Rees has held a senior lecturer appointment at the University of Bristol.

His research interests include the use of finite element analysis in biomechanics, tooth wear and tooth whitening and he has published over 100 papers in refereed scientific journals.

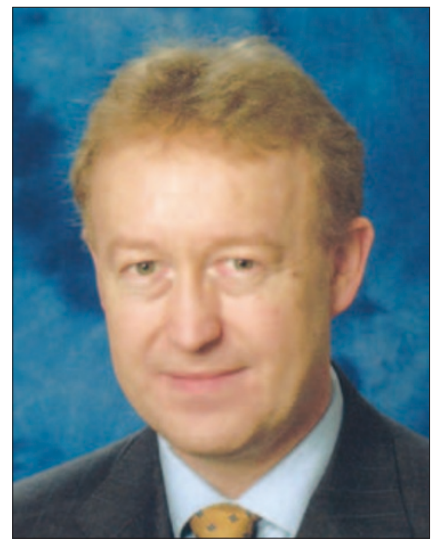

\title{
Dentist of the Year 2004
}

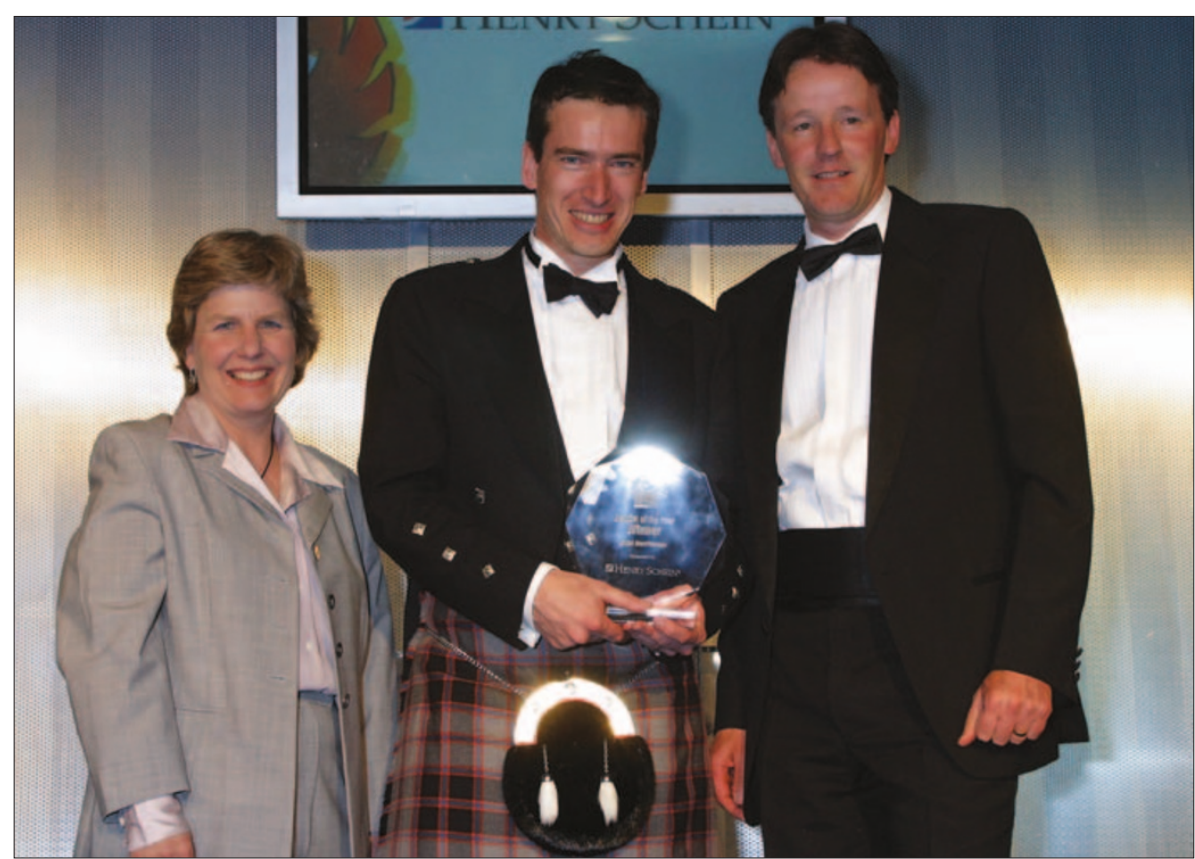

David MacPherson of Whitemoss Dental Practice, East Kilbride (centre) won the award for Dentist of the Year at The Dental Awards 2004 which took place at the Royal Lancaster Hotel in London. The People's Awards for Patient Care went to dentist Adrian Reed of Ashley Down Dental Care in Bristol while the Lifetime Achievement Award was presented to Professor Martin Addy.

\section{New registration process for EU PCDs}

The GDC is to introduce a new registration process for dental hygienists and therapists who come from the European Union, Norway, Iceland or Switzerland.

From 1 May 2004 nationals of these countries will have their applications individually assessed by external assessors. The assessors, who are all dental training experts, will compare the applicant's qualifications, training and professional experience with UK standards and will then recommend whether or not the person is adequately qualified and skilled to be enrolled with the Council and allowed to work in the UK.

Under European Union rules a person who fails such an assessment can choose to undergo a period of extra supervised training, to make up the lack of experience or knowledge, or can decide to sit an examination.
The General Dental Council decided to introduce the new procedures in order to be able to check the training standards of dental hygienists and therapists from all the EU countries - including the ten new countries which joinined the EU on 1 May - plus Norway, Iceland and Switzerland. It claims that the new individual assessment of applications will help it to check standards and protect the public.

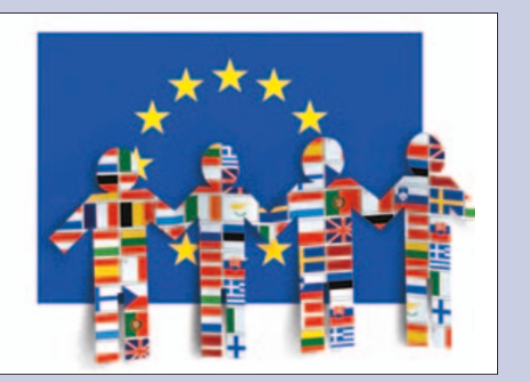




\section{DIARY}

June 2004

LDC Annual Conference

Date: 10-11.06.04

Venue: International Hotel, Docklands

London

Contact: Kath Blacker, Events Office

Tel: + 44 (0) 2075634590

Email: events@bda.org

BDA/BDJ Clinical Seminar: Periodontology Date: 25.06.04

Venue: Holiday Inn, Oxford

Contact: Kath Blacker, Events Office

Tel: + 44 (0) 2075634590

Email: events@bda.org

The British Fluoridation Society

Date: 28.06.04

Venue: Royal College of Physicians, London

Contact: Sheila Jones

Tel: + 44 (0) 1612205223

Email: bfs@bsfweb.org

www.bsfweb.org

\section{August 2004}

8th Congress of International Congress of Oral Implantologist/Asia Pacific Section \& 20th International Symposium of the Asian Oral Implant Academy

Date: 27-29.08.04

Venue: The New Otani, Singapore Contact: The ICO/AP-AOIA Meeting Secretariat

Tel: 67343162

Email: singdent@singnet.com.sg http://web.singnet.com.sg/ qualiser/me eting.html

\section{New Central Counties President}

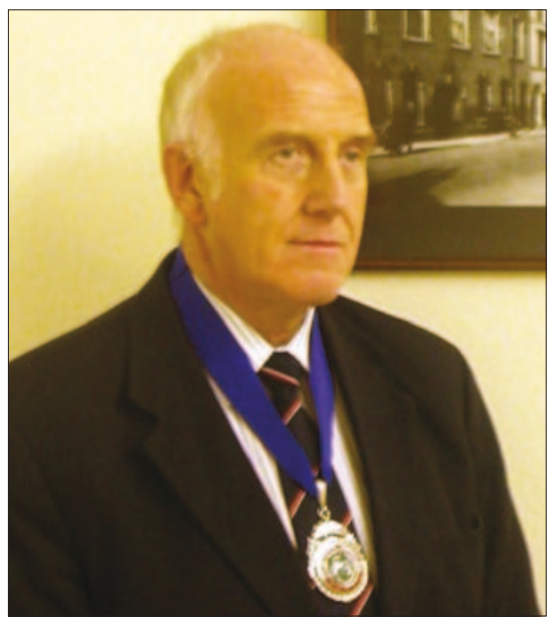

Dr John Walker has recently been elected the President of Central Counties British Dental Association.

The Central Counties area covers most of the West Midlands with around 1200 dentists.

He has practised in Dudley since 1967 when he joined Castleview Dental Practice.

He is presently the Secretary of the Dudley Local Dental Committee and a member of the Dudley Beacon \& Castle Primary Care Trust Services Committee that will be responsible for the delivery of primary care dentistry from April 2005.

\section{Non-American elected as APS President}

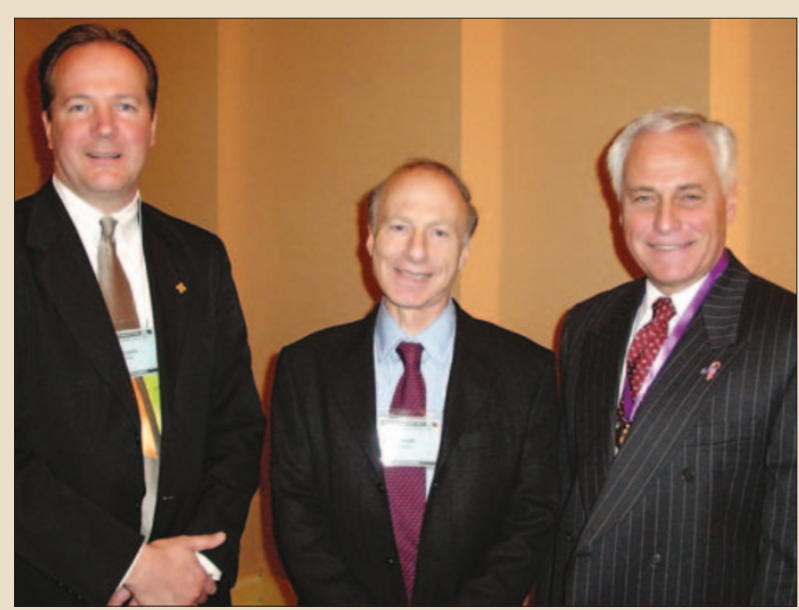

American Prosthodontic Society officers for 2004-05, (from left to right) Dr Dennis Stiles (US), President-Elect, Dr Harold Preiskel (UK), Vice President, Dr Gary Goldstein (US), President.
The American Prosthodontic Society (APS) have announced that for the first time in their 76 year history they have appointed a non-American to serve as a President of the society.

Dr Harold Preiskel of London has been elected to serve as Vice President for the year 2004 and will move through the officers' chairs to his Presidential year of 2006.

The APS is an international society, including specialists, generalists and dental technologists. 


\section{liP for orthodontic team}

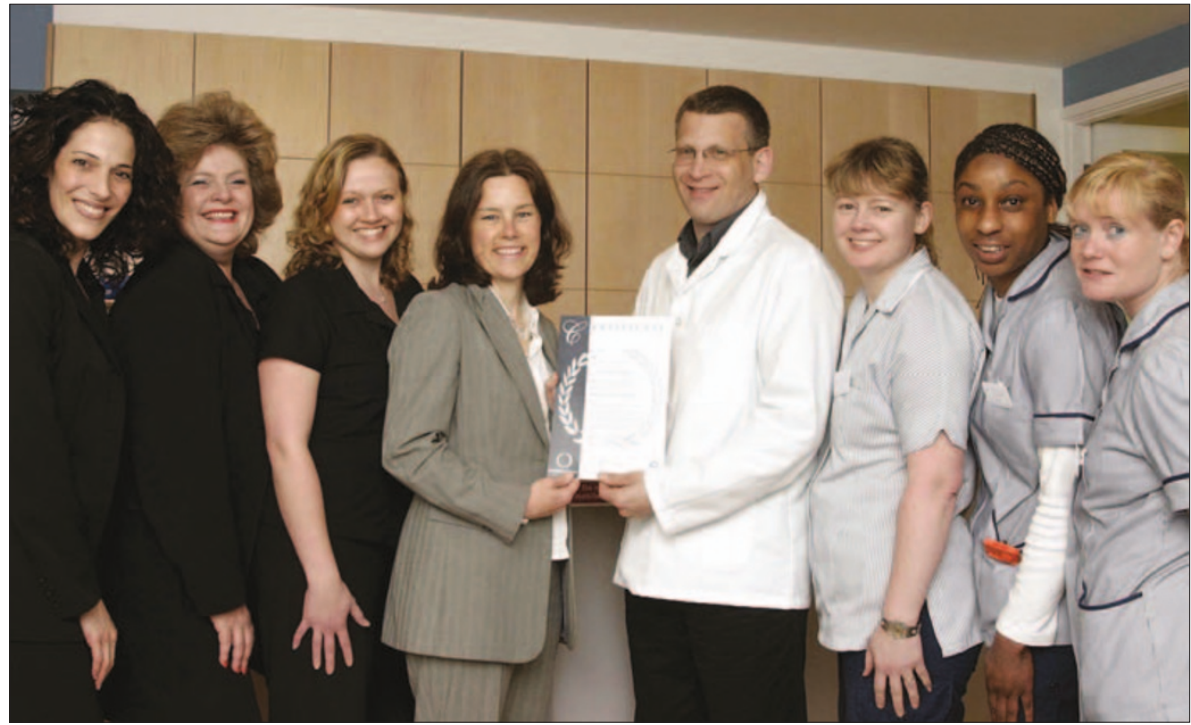

The team at Stevenage Orthodontics celebrated achieving the Investor in People award exactly a year and a day after the practice first opened in March 2003. Principal orthodontist, Jonathan Alexander-Abt, has been practising orthodontics for over eleven years and established the centrally located, predominately NHS specialist practice in Stevenage. Above: Orthodontist Jonathan Alexander-Abt, (fourth from right) with Melanie Broad of Herts Business-Link (fourth from left) and the Stevenage Orthodontics team.

\section{'Jail bird' raises money for charity}

Dr Kieron Fallon from Royston Dental Practice in Glasgow raised £2000 for leukaemia charity The Anthony Nolan Trust by being locked up in in police cells for two hours.

Participants in the 'Jail \& Bail' event handed themselves over to Strathclyde Police at Hampden Stadium in Glasgow in April and had to undertake to have raised at least £500 'bail' money.

Dr Fallon was nominated for imprisonment by staff at his practice, 'charged' with appropriate offences and was accused of 'murdering' a Dr Kieron Fallon (left) with fellow 'inmates' song at a staff karaoke party. Patients, staff,

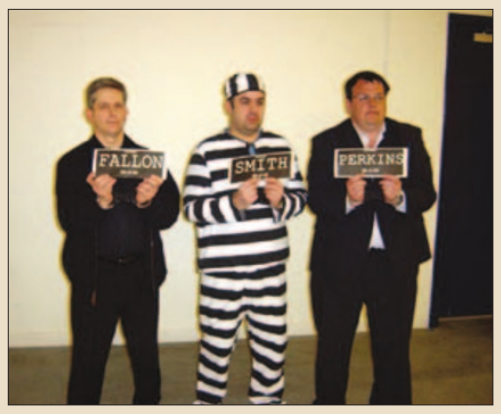

friends and colleagues pledged money to help him raise the cash. It will be used to recruit more donors for the charity's life-saving register which offers the only chance of life to thousands of leukaemia patients each year.

\section{New appointment for ADI}

Paul Stone recently became the new President of the Association of Dental Implantology (ADI) at its elections for its first democratically appointed committee.

An oral surgeon from Perth in Scotland, he has been placing and restoring implants for over 15 years, both privately and within the NHS hospitals implant programme in Tayside.

Dr Stone has stated that his priority for the two year term of office is to try to bring about a registerable qualification in implant dentistry that is available to all clinicians who have reached an appropriate level of experience. There are currently over 1000 members of the ADI in the UK.

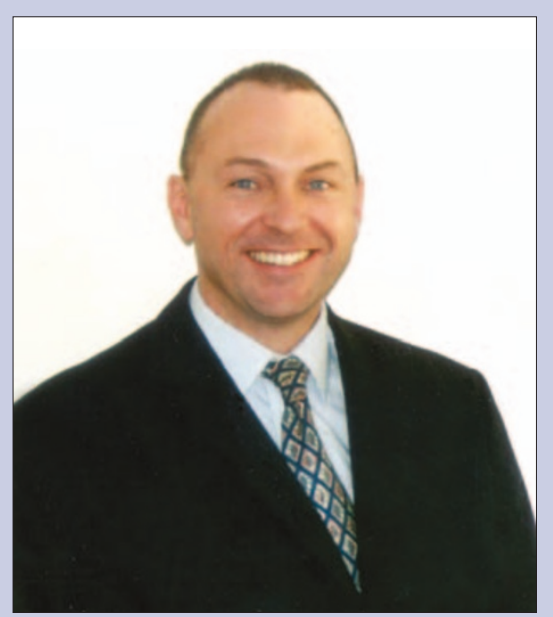

